\section{Religion and Prison}

Dan Micklethwaite and Belinda Winder

Sexual Offences, Crime and Misconduct

Research Unit, Department of Psychology,

Nottingham Trent University, Nottingham, UK

\section{Why Are People Religious?}

The earliest indicators of religion have been detected alongside the earliest signs of human life. The human race has embraced religion in its many forms, which prompts the question of "why?" Why are humans religious? Psychologists and anthropologists have offered several explanations for our adoption of religion. Barrett (2001) asserted that religion is "a social construct encompassing beliefs and practices which enable people, individually or collectively, to make some sense of the Great Questions of life and death" (p. 25). Religion is a means of managing fear, uncertainty, and a lack of control over events in our lives. There is also a sense in which religion may be seen to protect us - if we worship, or pay reverence, to particular deities, they may keep us safe.

An alternative psychological explanation for the emergence of religion fits under the growth/ realization tradition in positive psychology. This can be related to the experience of "flow" experiences (Csikszentmihalyi and Csikszentmihalyi 1975) in which we have a highly satisfying experience, characterized by a sense of control, unity, concentration, and time distortion. Religion as growth also maps onto Maslow's (1954/1987, 1964) final stage in the hierarchy of motivation for humans, that of self-actualization, in which individuals seek personal growth and fulfilment. Maslow asserted that self-actualizing individuals achieved "peak experiences" (p. 163), which he described thus: "a complete, though momentary loss of fear, anxiety, inhibition, defense and control ... The fear of disintegration and dissolution, the fear of being overwhelmed by the 'instincts,' the fear of death and of insanity, ... all tend to disappear or go into abeyance for the time being" (p. 163). From this perspective religion, perhaps, provides a means for prisoners to pursue this selfactualization despite the harsh pressure of the prison environment.

\section{Why Are People Religious in Prison?}

Prisoners may gain a number of direct and indirect benefits from being religious. Such benefits may be practical, psychological, and/or social.

\section{Trauma}

One of the most difficult stages of the prison sentence is the induction into the prison and its disorientating processes of identity theft: "the attack against the self, represented by the prison 
term, is too real to be denied" (Clear et al. 2000, p. 57). Most suicides tend to occur in the early stages of a sentence (Birmingham 2003). Religion can play an important role in the way the individual can cope with the trauma of going to, and living in, prison.

\section{Prisoner Codes of Behavior}

Being religious often means following specific rules. These may be in contradiction to prisoner codes. In prisoner society, aggression, violence, and intimidation are common practices (De Viggiani 2012). Involvement in religion can help to bring positive structure to the prisoner's life. Clear et al. (2000) explain that structure is a means of achieving and maintaining good conduct in prisons. Structure brings the development of habitual behavior, which, when framed in religious terms, can help the avoidance of conflict or breaking of prison rules and boundaries. For example, the use of illicit drugs, the bullying of other prisoners, and a means of making one's prison sentence feel less like a waste of time out of a finite life span.

\section{Repentance}

A study by the U.S. Department of Justice showed that $32 \%$ of prisoners undertook religious activities such as Bible study and church services (BJS 1993). This is evidence that religion is a significant part of both prisoner life and the way prisons interact with prisoners. Dammer (2002) explores the role of religion in prisons and unpacks the notion that religion has long served as a means for prisoners to repent, for them to seek absolution, and for them to atone for their moral transgressions.

\section{Real and Fake Rehabilitation}

Dammer (2000) explains religion has long been adopted by forms of rehabilitation in the Western prisons movement. Religion has had a place in prisons for as long as prisons have been used as places of punishment. Prisoners have adapted to use religion for authentic and less authentic purposes: religion can be a genuine part of identity or a way to pretend they have changed.

\section{Identity}

\section{Prisoner Context}

Prisons have far-reaching effects on self and social identity. Prisons affect how people think and feel about themselves and others, and thus how they behave. Sykes (1958) produced his classic model of deprivation to explain prison sociology. Upon prison induction, the prisoner is deprived of access to services and goods, to normal social relations and family members and is subjected to a form of symbolic castration (deprivation of heterosexual relations). Crewe (2012) explores the infantilizing effects of the management model of dealing with prisoners; treating prisoners as entities requiring supervision before rehabilitation. Within this management model are the administrative processes that cause frustration for the prisoner. De Viggiani (2012) unpacks the masculine nature of prison wings and the need for prisoners to present an artificial front in order to prevent victimization and maintain social status. This literature demonstrates the notion that induction into a prison is a process of dehumanization that necessarily strips the individual of their identity. Examples include the use of prison numbers for all prisoners, the use of surname over forename by prison personnel when addressing prisoners and the requirement to wear standard issue prison clothes.

\section{The Prison Chaplain}

Religious figures provide positive influence in many respects within prisons (Perrin et al. 2018). They provide support for vulnerable prisoners and poor copers, adding valued structure in the often fragmented lives of prisoners. Chaplains can be a source of advice and guidance on personal issues and also prison processes. Prison chaplains have 
evolved, in many instances, to become an important piece of overall prison management strategy.

\section{To Be Someone Other than a Prisoner}

For many prisoners, considering a crime-free life is a complex process. Many prisoners have deep set and negative values and ideas about who they are and what they can achieve. Prisoner life before, or in-between, prison sentences is typically characterized by poor community cohesion (Petersilia 2000), unemployment, poor educational achievements, substance abuse, antisocial behavior, and unhealthy personal relationships. Religion can offer a different path. It can help prisoners to learn new values and practice prosocial interactions. Fundamental for many religious faiths is the individual intention to be good; to be a good person. This has potential for helping prisoners to begin to value themselves; prisoners are people before they are prisoners. This is an essential factor in prisoner rehabilitation, a factor that religion acknowledges. If prisoners can believe that they are fundamentally good and that they can lead different lives, then they can develop healthy self-esteem; this is a key ingredient for building a healthy identity. This can be an identity that influences engagement with many other beneficial parts of normal everyday life. For example, engagement in religious communities, charitable events, and the support of others. This can become a reinforcing cycle of individual affirmation and a healthy reminder that many prisoners are as morally developed as those in the free world.

Religion can offer avenues for redemption and forgiveness and provide insight into moral and compassionate thinking while providing a means of reflection upon one's crime and life history. For example, Christians can repent, Muslims can pray, and Buddhists can meditate upon right action and undoing bad karma. Religion can be viewed through a lens of repair and restoration. This can become specifically significant for those convicted of a sexual offence. Maruna (2001) presents the idea of narrative reconstruction: a process of examining one's past and making meaning or reconstructing in a way that provides believable meaning. For those that have committed serious and stigmatized crimes, religion can provide a means of identity reconstruction and an attempt to come to terms with one's past actions.

\section{Religious Conversion in Prison}

For prisoners, converting to a religious faith can hold potential for personal growth and provide an initial step toward building a positive identity. Most religions advocate concepts of forgiveness, compassion, and reparation. This fits with the idea that prisoners should learn from their mistakes, have empathy for their victims and remorse for their crimes. Within the prison environment, religious conversion enables the prisoner to present an identity that may help keep some of the pitfalls of a prison sentence at bay. For example, involvement in substance abuse, bullying, and violence. This religious identity also enables the prisoner to demonstrate that they are making good (Maruna 2001); the idea that they have changed their ways and are committed to living better lives. For prisoners, especially long serving prisoners, this can be an important part of the prison journey. There is of course the notion that some prisoners adopt religion as a means of persuading others (perhaps even themselves) that they have changed. Yet for most, religion conversion signals a genuine attempt to build a new, healthy, personal, and social identity.

\section{Religion as a Means of Coping with Prison}

Prison can be a lonely place. Religion offers the opportunity for inclusion into a group. Because of the religious basis of these groups, there is little judgment regards past offending; people are accepted and can obtain a status of meaning (feeling valued). This meaning is symbolic of power and control. Therefore, this can become an identity that offers security, because the prison cannot take it away; it provides a sense of identity, security, and protection. Prisons are obligated to 
cater for prisoner religious beliefs and needs: not to do so would be discriminatory. These groups offer to help make prisoners feel as though they have a sense of power; they have a social group that provides a sense of security and belonging.

\section{The Power of Symbols for Identity in Prison}

Prisoners are deprived of many of the things available to those in the free world. The restriction of access to material goods and services (Sykes, 1958) also deprives the prisoner of many of the things that inhabit normal free everyday life. As a consequence, ideas and imagination become ever more important resources to the prisoner as a means of filling time and keeping the mind active. Michalski (2015) argues that imprisonment influences prisoners to place increasing value on the symbolic meaning of things. Although this idea is used to explain violence in prison, as the symbolic meaning of respect and reputation become more valuable, this can be applied to the way in which religion can become more valuable. Religion is steeped in symbolic meaning and requires the discipline of faith. The prisoner does not necessarily need access to goods or services to believe, and the positive beliefs around religious symbols can provide comfort for struggling prisoners. In an environment that requires the use of the symbolic (which means all things imagined or intangible) as a means of healthy psychological survival, religion can become a beneficial tool. Being religious in prison may bring additional benefits, whether it be specially prepared food, being able to own or use novel items (e.g., incense sticks), or have special clothing. These small benefits might seem insignificant to the public, but for prisoners, they represent material gain, empowerment, and a sense of social status.

\section{Rehabilitation}

Adherence to a religious code, such as praying in Islam and meditating in Buddhism requires effort. The discipline required to commit to a religion can be viewed from different perspectives. The idea of rehabilitation requires one to take control of the mind and body, to be responsible for behavior. Prisoners who abide by a strict religious code are proving that they can do this. This can be viewed as congruent with many notions of cognitive behavioral intervention (McGuire 1995) in prisons as it demonstrates one can make a conscious choice to act and behave in a desired way. This means that people can develop habits that can, over time, become part of their identity.

\section{Summary}

The impact of religion upon the dynamic of prisoner individuality and prisoner sociology is a complex issue. Many prisons now utilize multifaith rooms rather than traditional Christian chapels and the range of religions that the prison system caters for is expanding. This is a necessary progression with social climate in the free world. Religion in prisons plays an important role in the way in which prisoners cope and adapt to their environment. Religion poses an avenue for redemption and forgiveness; it affords sense of security and power, while also providing an opportunity for the construction of a new identity. In prisons, religion can be a positive influence in numerous ways - a prosocial identity, ability to cope, ability to see a positive future, but it may also be a means of manipulating attitudes or gaining special privileges.

\section{See Also}

\author{
- Clergy Sexual Abuse \\ - Conscience \\ $\checkmark$ Desistance \\ - Empirical Research \\ - Forgiveness and Religious Tradition \\ - Maslow, Abraham \\ - Offending \\ - Religious Abuse/Violence \\ Will/Free Will
}




\section{Bibliography}

Barrett, D. V. (2001). The new believers: Sects, “cults" \& alternative religions: A world survey and sourcebook. London: Cassell.

Birmingham, L. (2003). The mental health of prisoners. Advances in Psychiatric Treatment, 9(3), 191-199.

Clear, T. R., Hardyman, P. L., Stout, B., Lucken, K., \& Dammer, H. R. (2000). The value of religion in prison: An inmate perspective. Journal of Contemporary Criminal Justice, 16(1), 53-74.

Crewe, B. (2012). The prisoner society: Power, adaptation and social life in an English prison. Oxford: OUP.

Csikszentmihalyi, M., \& Csikszentmihalyi, I. (1975). Beyond boredom and anxiety (Vol. 721). San Francisco: Jossey-Bass.

Dammer, H. R. (2000). Religion in corrections. Lanham: American Correctional Association.

Dammer, H. R. (2002). The reasons for religious involvement in the correctional environment. Journal of Offender Rehabilitation, 35(3-4), 35-58.

De Viggiani, N. (2012). Trying to be something you are not: Masculine performances within a prison setting. Men and Masculinities, 15(3), 271-291.

Irwin, J., \& Cressey, D. R. (1962). Thieves, convicts and the inmate culture. Social Problems, 10(2), 142-155.

Maruna, S. (2001). Making good (p. 86). Washington, DC: American Psychological Association.
Maslow, A. H. (1943). A theory of human motivation. Psychological Review, 50(4), 370.

Maslow, A. H. (1954). Motivation and Personality. New York: Harper and Row.

Maslow, A. H. (1964). Further notes on the psychology of being. Journal of Humanistic Psychology, 4(1), 45-58.

Maslow, A., \& Lewis, K. J. (1987). Maslow's hierarchy of needs. Salenger Incorporated, 14, 987.

McGuire, J. E. (1995). What works: Reducing reoffending: Guidelines from research and practice. Chichester: Wiley.

Michalski, J. H. (2015). Status hierarchies and hegemonic masculinity: A general theory of prison violence. British Journal of Criminology, 57(1), 40-60.

Perrin, C., Blagden, N., Winder, B., \& Norman, C. (2018). Religion and desistance: Working with sexual and violent offenders. Finding freedom in confinement: The role of religion in prison life, 24-41.

Petersilia, J. (2000). When prisoners return to communities: Political, economic, and social consequences. Federal Probation, 65, 3.

Sykes, G. M. (1958). The society of captives: a study of maximum security prison. Princeton, NJ: Princeton University Press.

Sykes, G. M. (2007). The society of captives: A study of a maximum security prison. Princeton: Princeton University Press.

U.S. Department of Justice (1993). Survey of inmates, 1991. Washington DC: Bureau of Justice Statistics. 